\title{
BUSINESS COURTS: THEIR ADVANTAGES, IMPLEMENTATION STRATEGIES, AND INDIANA'S PURSUIT OF ITS OWN
}

\author{
TYLER MOORHEAD*
}

\section{INTRODUCTION}

Since Delaware established its Court of Chancery over two hundred years ago, the United States has seen a progressive movement towards specialization within its court system. ${ }^{1}$ As states have implemented courts to handle bankruptcy, taxes, and juvenile issues, many states have begun seeking a court system dedicated to business disputes. ${ }^{2}$ In an effort to alleviate the chaotic problems associated with complex business, supplier, and consumer relationships, many states are creating business courts within their jurisdictions. ${ }^{3}$ Currently, over half of the states in the nation have chosen this strategy and have implemented some type of business court or complex litigation court. ${ }^{4}$

A business court, also referred to as a commercial court, is a state program that is dedicated to specifically handling business disputes or complex litigation within its respective jurisdiction. ${ }^{5}$ The term "court" can be misleading. ${ }^{6}$ A business court is a program, not necessarily a specific courtroom, typically created within a state's existing trial court or civil division. ${ }^{7}$ The majority of business courts have several common, fundamental building blocks that allow them to remain successful. ${ }^{8}$ In every business court, judges are trained and assigned to the court to handle complex business disputes specifically, and that single judge handles all aspects of the case from beginning to end. ${ }^{9}$

* J.D. Candidate, 2017, Indiana University Robert H. McKinney School of Law; B.S., 2014, Indiana University's Kelley School of Business. A special thank you to Judge Heather Welch and Justice Steven David for their encouragement to pursue this topic and to Professor Frank Sullivan for his continued support and insight into the Commercial Court Working Group.

1. Anne Tucker Nees, Making a Case for Business Courts: A Survey of and Proposed Framework to Evaluate Business Courts, 24 GA. ST. U. L. REV. 477, 480-81 (2007).

2. Pamela J. Roberts et al., South Carolina's Business Court Pilot Program, 19 S.C. LAw. 30,32 (2008).

3. $I d$.

4. See generally Richard L. Renck \& Carmen Thomas, Am. Bar Ass'n, The Nationwide InNovation of Specialized Business and Commercial Courts for EFFective Resolution of Business Disputes: Summary of Resources And Courts (2014), http://www.americanbar.org/content/dam/aba/publications/blt/2014/05/courts-summary201405.authcheckdam.pdf [https://perma.cc/52ML-UXTR].

5. Roberts et al., supra note 2, at 31 .

6. Lee Applebaum, The "New" Business Courts: Responding to Modern Business and Commercial Disputes, 17 Bus. L. TODAY 13, 14 (2008).
7. Id.
8. Id.
9. Id. 
The logic behind implementing a business court is that it streamlines the court's efficiency, educates judges and litigants, and creates predictable business case law that encourages companies to incorporate or complete transactions within the state. ${ }^{10}$ By taking complex cases that would otherwise force judges to learn the business law as the case develops, and assigning those cases to trained judges, the process frees up the docket and decreases the amount of time spent on expensive litigation. ${ }^{11}$

However, business courts are not without their fair share of skeptics and concerns. ${ }^{12}$ Some critics believe that business courts foster a pro-business public perception, isolate judges from other important areas of law, and create an elitist court full of the most educated judges who are only focused on businesses. ${ }^{13}$ However, these concerns are not justified and are easily remedied by regulatory procedures; the benefits a business court can provide a state far outweigh any negative concerns. ${ }^{14}$

There are a number of decisions that a state must make to establish a successful business court. ${ }^{15}$ Factors such as which cases qualify for the business court, filing fees, jury trials, location of the court, selecting judges, and establishing pilot program policies all have an impact on whether a business court will be effective. ${ }^{16}$ By following the policies implemented by the most successful business courts in the nation, any state can establish a business court to overcome the hardships of complex business litigation within its jurisdiction. ${ }^{17}$

As of June 2, 2015, Indiana recognized the benefits a business court can provide and has initiated its pursuit for one of its own. ${ }^{18}$ The Indiana Supreme Court created the Commercial Court Working Group to offer proposed next steps and a draft of rules governing Indiana's commercial court. ${ }^{19}$ The Working Group has provided the Indiana Supreme Court with recommendations, including solutions to case eligibility requirements, publishing opinions, funding staff, and educating the community. ${ }^{20}$ The Indiana Supreme Court has since accepted the

10. See generally Frank Sullivan, Jr. \& Audrey Wessel, Preliminary Report on EstABLISHING AN INDIANA Business COURT (Sept. 24, 2013) (unpublished report) (on file with authors).

11. Id. at $2-3$.

12. Id. at 4.

13. See Nees, supra note 1 , at 493-99.

14. See generally Andrew A. Powell, It's Nothing Personal, It's Just Business: A Commentary on the South Carolina Business Court Pilot Program, 61 S.C. L. REV. 823, 835-39 (2010).

15. See generally Sullivan \& WeSSEL, supra note 10 , at 5 .

16. Id. at 5-7.

17. See generally Nees, supra note 1.

18. Ind. Commercial Court Working Grp., initial Report of the Indiana Commercial Court Working Group to the Indiana Supreme Court 1 (Sept. 30, 2015) (on file with author) [hereinafter INITIAL REPORT].

19. Id. at 1-2.

20. See generally id. at 2-9. 
Working Group's recommendations and unanimously decided to institute the Indiana Commercial Court Pilot Project by June 1, 2016. ${ }^{21}$

Part I of this Note explains the fundamental elements of a business court and its purpose within the judicial system. ${ }^{22}$ Part II covers the numerous benefits a business court is able to provide its respective state. ${ }^{23}$ Part III will discuss, and challenge, the negative perspectives sometimes associated with business courts. ${ }^{24}$ Part IV contains an analysis of important decisions a state must determine before implementing a business court within its jurisdiction. ${ }^{25}$ Part $\mathrm{V}$ provides recommendations on how states can establish a successful business court by implementing proven strategies. ${ }^{26}$ Finally, Part VI specifically analyzes how Indiana has taken on these challenges and where the progress of its business court currently stands. ${ }^{27}$

\section{AN EXPLANATION OF BUSiness COURTS}

The increase in large, globalized companies over the last several decades has brought with it a need for state trial courts to establish business courts that can effectively litigate their complex disputes and consumer transactions. ${ }^{28} \mathrm{~A}$ total of twenty-seven states, including business centers such as New York, Illinois, Rhode Island, Nevada, and Delaware, now maintain business courts to streamline this litigation that would otherwise bog down an unprepared civil court staff. ${ }^{29}$ Though the majority of states have caught on to this trend rather recently, the "grandfather" of all business courts started with the Delaware Court of Chancery in $1792 .{ }^{30}$ Because Delaware's equity cases generally raised issues that coincided with many business issues-duty to disclose, good faith requirements, injunctions, specific performance, accountings, etc.- the Delaware Court of Chancery shed light on the benefits of specialization as it effectively resolved these business disputes. ${ }^{31}$

Corporations have played a significant role in shaping modern society, and their influence in the legal profession is no exception. ${ }^{32}$ Many states believe that

21. Letter from Chief Justice Loretta H. Rush, Chief Justice, Indiana Supreme Court, to Craig J. Bobay, Judge, Allen Superior Court, Civil Div. (Oct. 29, 2015) (on file with author) [hereinafter Letter]; Order Establishing the Indiana Commercial Court Pilot Project, No. 94S00-1601-MS-31, 2016 Ind. LEXIS 29 (Ind. Jan. 20, 2016) [hereinafter Order].

22. See infra Part I.

23. See infra Part II.

24. See infra Part III.

25. See infra Part IV.

26. See infra Part V.

27. See infra Part VI.

28. Applebaum, supra note 6 , at 13 .

29. RenCK \& ThOMAs, supra note 4 , at 3-8.

30. Nees, supra note 1 , at 480.

31. Id. at 480-82.

32. Id. at 482 . 
these corporations' prevalence and importance to the continued development of the economy justify the use of state resources to better serve the legal industry's needs at large. ${ }^{33} \mathrm{~W}$ ith commercial litigators, securities prosecutors, transactional attorneys, and securities attorneys, many states have recognized the need to merge the legal and corporate professions by providing a concentrated platform, such as a business court, to specifically target and resolve these business-centered issues.

\section{The Benefits of a Business Court Program}

In the competitive economy of today's corporate landscape, states are implementing business court programs to secure advantages, such as judicial efficiency, judicial expertise, and a streamlined docket. ${ }^{34}$ Though targeted at complex litigation and business disputes, a business court is beneficial to a state's entire judicial landscape. These courts consolidate and efficiently resolve disputes that otherwise would delay any case scheduled near it on the docket. ${ }^{35}$ As centers of quality, technology, and innovation, business court programs provide benefits that are admired by corporate litigants and court systems alike. ${ }^{36}$

\section{A. Efficiency}

Most participating states agree that the leading benefit a business court provides is the potential efficiency with which it resolves complex disputes ${ }^{37} \mathrm{~A}$ 2012 study that evaluated total case time measured in days and case complexity measured in docket entries, highlighted the efficiency for which business courts are known. ${ }^{38}$ The study found that business courts handled complex contract claims an average of 1138 days faster than regular civil courts. ${ }^{39}$ The same study showed business courts handled complex tort-based claims an average of 718 days faster than civil courts. ${ }^{40}$

The fact that it is mandatory in a business court for a single judge to preside over the entire case is one reason for this level of efficiency. ${ }^{41}$ The judge will be readily familiar with the facts of the controversy and the procedural history instead of requiring a summary at every stage of the litigation process. ${ }^{42}$ This also gives the judge a chance to manage the discovery, motion deadlines, hearing dates, and designations of evidence with an eye towards the trial or final stages

33. Id. at 491-93.

34. Sullivan \& Wessel, supra note 10 , at 1.

35. See generally John F. Coyle, Business Courts and Interstate Competition, 53 WM. \& MARY L. REV. 1915 (2012).

36. Id.

37. Richard L. Renck \& Carmen H. Thomas, Recent Developments in Business Commercial Courts in the United States and Abroad, Bus. L. TODAY, May 2014, at 1.

38. Id.

39. Id.

40. Id.

41. Roberts et al., supra note 2, at 32-33.

42. Id. 
of the dispute over which he or she will also preside. ${ }^{43} \mathrm{~A}$ judge not presiding in a business court may have the option to devote his or her limited time between managing one complex oral argument or handling a dozen smaller cases. ${ }^{44} \mathrm{By}$ taking the complex issue off the judge's plate and placing the case in an established business court, the judge can dedicate his or her time to the other dozen cases, and the entire system benefits because the process is effectively streamlined in a manner that expedites cases backing up the docket. ${ }^{45}$

\section{B. Knowledgeable Judges}

A report from the American Bar Association stated that the "hallmark of every business court" is the ability to have one trained judge preside over the case from beginning to end ${ }^{46}$ Business court judges typically volunteer to be assigned to the business court docket and, therefore, are generally experienced and passionate about corporate law issues. ${ }^{47}$ These judges have a greater opportunity of setting realistic compromises and potential resolutions because of his or her experience with various business operations. ${ }^{48}$ A report from the South Carolina Business Court stated its cases encountered pre-trial disposition more frequently than any other civil cases and that, because of the single judge principle, "unique opportunities to resolve business cases are not lost." ${ }^{49}$ As these judges become more familiar with common business disputes within their jurisdictions, their knowledge of business matters will increase and, in return, their efficiency will as well. ${ }^{50}$

Constantly appearing before the same judge also has the added benefit of providing continuity throughout the proceedings and eliminating surprises that may be uniquely attributed to each new judge..$^{51}$ Complex business disputes are a difficult breed of litigation that warrants the special attention these judges can provide the litigating parties. ${ }^{52}$ Many complex business disputes have extensive pleading schedules, multiple parties, cross claims, complicated discovery schedules, large electronic documents, and a need for responsive judges who can quickly schedule hearings to rule on matters in a timely fashion. ${ }^{53} \mathrm{~W}$ ith the increased presence of judicial congestion, the amount of time these judges save leads to a large decrease in litigation expenses for each party involved. ${ }^{54}$

43. Id.

44. Nees, supra note 1 , at 487.

45. Id.

46. Sullivan \& WeSSEL, supra note 10 , at 2 .

47. Id.

48. Id.

49. Id.

50. Id. at 3 .

51. Roberts et al., supra note 2 , at 32.

52. Nees, supra note 1 , at 484-85.

53. Id. at 484 .

54. Id. at 484-85. 


\section{Common Law Predictability}

Complaints of the inconsistent application of business law, as well as a lack of alternative dispute resolution options, both govern a corporation's decision on where to file suit. ${ }^{55}$ These complaints have driven litigating corporations to "federal court[s], to states with business courts . . or to private adjudication.",56 Because business courts publish opinions at the trial court level, the body of common law governing business cases will increase and become more uniform as more states adopt business court programs. ${ }^{57}$ For example, this body of common law makes pre-trial disposition more common and efficient by establishing straightforward law that explains the often complex statutes associated with business disputes. ${ }^{58}$ By establishing predictable business case law, a state can effectively give corporations an incentive to conduct transactions within the state and potentially even incorporate there. ${ }^{59}$ A business court is a means to assure corporations that the state has the resources to handle its disputes and will effectively resolve its suit with precedent or deliberate reasoning. ${ }^{60}$ This gives a state with a business court program an advantage over neighboring states that might lack this judicial advantage. ${ }^{61}$

The large number of companies incorporated on the east coast may correlate to the benefits and security business courts have provided to these corporations. ${ }^{62}$ For example, PepsiCo lawyers expressed a desire to have access to a business court that offered security in the form of predictable case law. ${ }^{63}$ The company ultimately reincorporated in North Carolina and considered the state's successful business court as one of the factors in choosing the correct location. ${ }^{64}$

In summary, a business court provides predictable case law that incentivizes corporations to do business within the state and allows a company to be fairly represented by local counsel within the state court system. ${ }^{65}$ Corporations and their general counsels are not the only target market for business courts, as lawyers within the state also receive a benefit from the program. ${ }^{66}$ A 2002 study showed that a state's lawyers received on average $\$ 4.5$ million in additional revenue for every percentage point increase in the number of businesses

55. Id. at 488 .

56. Id.

57. Sullivan \& Wessel, supra note 10 , at 3.

58. Id.

59. Id.

60. Applebaum, supra note 6, at 16.

61. Id.

62. $I d$.

63. Roberts et al., supra note 2, at 33 .

64. Id.

65. Nees, supra note 1 , at 491.

66. Id. at 492 . 
incorporated within the state. ${ }^{67}$ The more companies a business court can persuade to incorporate within the state, the more its legal and state-wide economy will benefit. ${ }^{68}$

\section{Technology and Innovation}

Another benefit commonly associated with a business court is that it offers cutting-edge technology in an effort to maintain its promised efficiency and to continue to incentivize businesses to file claims within its jurisdiction. ${ }^{69}$ Access to electronic filing is often sufficient motivation for corporate attorneys to file claims within the business court. ${ }^{70}$ The extensive discovery and file sizes of business litigation almost make electronic filing a necessity. ${ }^{71}$ Having electronic documents stored on a searchable server greatly reduces the burden of organizing and reviewing the record for both judges and litigants alike. ${ }^{72}$

However, technology in business courts goes far beyond electronic filing. ${ }^{73}$ For example, South Carolina's business court offers video conferencing as a resource for litigants to use. ${ }^{74}$ This gives corporations the chance to appear for hearings without having to be physically present in the courtroom. ${ }^{75}$ Furthermore, "[e]lectronic presentations and technology-generated demonstrative evidence" allow for exhibits to be presented on large screens for all present in the courtroom to view in unison. ${ }^{76}$ In North Carolina, the witness stand is equipped with a touchscreen computer that may be used to demonstrate witness testimony. ${ }^{77}$ Collectively, these innovative technologies allow a business court to remain an attractive option for litigants to pursue their claims. ${ }^{78}$

\section{Misconceived Negatives Surrounding Business Courts}

Though many believe in the benefits business courts provide, business courts are not without their fair share of perceived negatives. ${ }^{79}$ Whether it be bias or concern for public perception or isolating judges, some states do not implement business courts for fear of change.$^{80}$ However, these negatives are often not

67. $I d$.

68. Id. at 492-93.

69. Sullivan \& Wessel, supra note 10 , at 3-4.

70. Id. at 3 .

71. Id.

72. Id.

73. Roberts et al., supra note 2, at 33 .

74. $I d$.

75. $I d$.

76. Id.; Sullivan \& WeSSEl, supra note 10 , at 4.

77. Powell, supra note 14, at 829.

78. Roberts et al., supra note 2, at 33.

79. See generally SulLIVAN \& WESSEL, supra note 10, at 4-5.

80. See generally Powell, supra note 14, at 836-39. 
warranted and are easily evaded by policies and corrective procedures. ${ }^{81}$

\section{A. Possible Bias}

Some individuals have expressed concern that a court devoted entirely to business disputes will show a bias favoring business entities and, thus, would have a perceived bias against individual litigants. ${ }^{82}$ The fear is that this perspective may make the judges susceptible to politicization and persuasion. ${ }^{83}$ This state of mind may erode one's belief in a fair and just courtroom proceeding governing his or her respective case ${ }^{84}$ If this fear becomes actualized, globalized companies with multiple locations that qualify for personal jurisdiction may forum shop for particularly sympathetic business court judges. ${ }^{85}$

However, these concerns are widely unsupported by recorded data. ${ }^{86}$ First, a court showing bias by continually ruling against individuals would erode the purpose of the judicial system and quickly gain widespread, negative attention that would put a stop to the prejudicial process ${ }^{87}$ Furthermore, procedural rules would prevent bias. ${ }^{88}$ For example, business courts like South Carolina's have appellate procedures that maintain control over business court rulings. ${ }^{89}$ The South Carolina Court of Appeals and the South Carolina Supreme Court effectively curb bias by maintaining the authority to overturn opinions of the business court with which they disagree. ${ }^{90}$

Additionally, business courts publish opinions in an effort to develop predictable common law and to remain completely transparent with litigating parties. ${ }^{91}$ With an exposed public record, it would be difficult for a judge to stray from the precedent established by other business court judges within his or her state. ${ }^{92}$ Also, most states rotate judges and closely collaborate with the state's bar association to keep policies and practices up to date. ${ }^{93}$ The American Bar Association has released a statement explaining, "[T]here is no record to prove that such a bias does, or could, exist." 94 The judges are experienced and have no reason to rule in a manner that contradicts the law or the precedent of the court. ${ }^{95}$

81. Id.

82. Sullivan \& Wessel, supra note 10 , at 5 .

83. Nees, supra note 1, at 494.

84. Id.

85. Id. at 495 .

86. Id. at 495-96.

87. Id.

88. Powell, supra note 14 , at 838 .

89. Id.

90. Id.

91. Nees, supra note 1, at 489-90, 521.

92. Id. at 521-22.

93. Id. at 497.

94. Sullivan \& WeSSEL, supra note 10 , at 5.

95. Id. 


\section{B. A Pro-Business Public Perception}

Another negative perception of business courts, which likely stems from the bias argument above, is the fear of a negative public perception surrounding these courts. ${ }^{96}$ States fear that citizens will lose faith in the judicial system because the name 'business court' implies that the court may be perceived as only assisting the business community and not the individual. ${ }^{97}$ Citizens might become averse to their public funds being used to train judges who solve disputes that are predominantly between two private entities. ${ }^{98}$

Almost every state with a business court widely disputes these arguments as false or misleading and instead argue that business courts are similar to other common specialized courts, such as family or juvenile courts. ${ }^{99}$ The American Bar Association has compared business courts to the less commonly known specialized courts, governing "mass torts, class actions, or medical malpractice." ${ }^{\prime 100}$ Furthermore, if a state is concerned that these misconceptions will exist, the state still maintains control as to which cases qualify for placement within its business court. ${ }^{101} \mathrm{~A}$ state could therefore only allow business versus business claims or complex individual claims to enter the court, and any fear about individual oppression would be adequately put to rest. ${ }^{102}$ There is no data to support the notion that a negative bias or public misconception actually exists. ${ }^{103}$

\section{Isolating Elite Judges}

Critics' arguments specifically against business court judges are two-fold: (1) business courts steal the most educated judges away from other claims that could benefit from their experience; and (2) these judges are isolated with only business claims and, therefore, lose touch with recent developments or trends in other areas of the law. ${ }^{104}$ The fear is that this isolation may also impact other judges by limiting their ability to collaborate with the business court judge about trends and recent legal developments. ${ }^{105}$

However, the fear of isolation is unfounded, as most courts, such as the South Carolina Business Court, maintain educational growth by requiring judges to carry a general docket as well as assigned business cases. ${ }^{106}$ Additionally, courts

96. Roberts et al., supra note 2, at 33.

97. Id.

98. Nees, supra note 1, at 481.

99. Roberts et al., supra note 2, at 33.

100. Sullivan \& Wessel, supra note 10 , at 4.

101. Id. at 1 .

102. Id.

103. Id. at 4 .

104. Powell, supra note 14, at 836-39.

105. Nees, supra note 1, at 496-97.

106. Powell, supra note 14 , at 838-39. 
still maintain typical appellate procedures should any dispute not be resolved with the most up-to-date legal theories. ${ }^{107}$ Regulating staffing and training mitigates many concerns that isolation brings with it. ${ }^{108}$ For example, "senior judges, rotating terms, continuing education, and interaction with multi-disciplinary associations such as a state or local bar association" provide the opportunity for judges to maintain exposure to other areas of law and to continue legal training. ${ }^{109}$

A similar argument critics of business courts make is that the courts create an elitist system by stealing away the best judges to solely rule on business disputes. ${ }^{110}$ This creates one elite judicial system solely for businesses and leaves the leftovers for everyone else. ${ }^{111}$ However, many of the arguments above solve this issue as well. ${ }^{12}$ Judges carry both types of cases, and additionally, a judge is often selected for his or her passion surrounding business, not because he or she is deemed more educated or superior to other judges. ${ }^{113}$ By taking these complicated cases off of the general docket, other cases actually benefit because the presiding judge has more resources to devote to the litigating parties. ${ }^{114}$

\section{Important Decisions a State Must Make Before IMplementing A Business Court Program}

Once a state determines a business court would be beneficial, there are a number of variables a state must choose for its program to make it the most effective for its specific goals. ${ }^{115}$ The variables represented below demonstrate variations that different states have chosen to pursue for their respective business court programs. Each state should choose a route that is most effective for its current economic and corporate landscape. ${ }^{116}$

\section{A. Types of Business Courts and the Cases Each Allows}

Perhaps the most important decision a state must make before implementing a business court program is which type of business court it wishes to have and, subsequently, which types of cases that court will hear. ${ }^{117}$ There are predominantly three types of business courts:

(1) 'pure business courts,' where the parties must be commercial entities but the dispute need not be complex; (2) 'complex business courts,'

107. Id. at 839 .

108. Nees, supra note 1, at 497.

109. Id.

110. Id. at 493; Powell, supra note 14 , at 836-37.

111. Powell, supra note 14 , at 837.

112. Id.

113. Id.

114. Nees, supra note 1, at 494.

115. See generally Sullivan \& Wessel, supra note 10 .

116. See generally Roberts et al., supra note 2 .

117. Sullivan \& WeSSEL, supra note 10 , at 1. 
where parties must be commercial entities and the case must be complex; and (3) 'complex civil courts,' where the parties need not be businesses, but the case must be complex. ${ }^{118}$

Pure business courts hear the majority of disputes arising between businesses, regardless of whether the case is complex. ${ }^{119}$ States that heavily litigate businessto-business issues such as breach of contract, breach of fiduciary duty, fraud, corporate structuring, partnership, and trade secrets tend to implement pure business courts to effectively handle these predominantly business disputes. ${ }^{120} \mathrm{In}$ an effort to determine the types of cases allowed, some courts include an exhaustive list of the various types of business claims that qualify, while others use catch-all phrases such as "the case is expected to have implications" on the corporate industry. ${ }^{121}$

Complex business courts require business entities to be the litigating parties and for the issue to be complex. ${ }^{122}$ Therefore, these types of business courts are slightly narrower than pure business courts. ${ }^{123}$ For example, Arizona uses a series of parameters to determine whether a business dispute is adequately complex to warrant transfer to its business court. ${ }^{124}$ Arizona measures the number of witnesses, parties, courts involved, supervision required, and legal issues. ${ }^{125}$ This ability to exclude non-complex business disputes helps establish greater efficiency and puts a focus on the more difficult issues that a typical court might not have the resources to handle. ${ }^{126}$

Finally, complex civil courts handle complex disputes, which usually means a business is involved, but there is no requirement that both parties be corporate entities. ${ }^{127}$ This type of court is becoming more common for states that want the benefits a business court brings but may not have the corporate landscape to fill a pure business docket. ${ }^{128}$ Claims such as environmental litigation, product liability, and consumer class actions usually fall within these complex case types. ${ }^{129}$ States choose this route because of the strong base of resources a business court has to offer, as well as the likelihood that a complex dispute will affect the

118. Id.

119. Id.

120. Id. at 7-8.

121. Id.

122. Id. at 1 .

123. Id.

124. Id. at 10 .

125. Id.

126. Id. at 4 .

127. Id.

128. Gary W. Jackson, Do Business Courts Really Mean Business? Many Nonbusiness Cases Are Being Transferred to Courts That Were Created to Streamline Disputes Between Companies. This Trend Weakens Consumer Protection, TRIAL (June 2006), http://www.thefreelibrary.com/ _/print/PrintArticle.aspx?id=147568319 [https://perma.cc/5MV4-2XVC].

129. Id. 
business community, regardless of whether a business is a party to the suit. ${ }^{130}$

\section{B. Location and Number of Judges}

Another fundamental decision in the implementation process is the location of the state's business court and the number of judges that should be assigned to it. ${ }^{131}$ Some states have started business courts in only the largest cities in terms of population or number of cases filed per year. ${ }^{132}$ Other states, such as Michigan, require a county to have a business court judge if the county typically has at least three circuit court judges. ${ }^{133}$ Other states only have business court judges in one county but have lifted jurisdictional barriers to allow anyone in the state to file there. ${ }^{134}$

Another option in determining the location of a business court is to divide the state into regions. ${ }^{135}$ For example, South Carolina is divided into three regions, and parties within those regions file their business disputes with the region's business court judge. ${ }^{136}$ Typically, a state will choose between one and three judges to assign to its respective business court. ${ }^{137}$ In an effort to provide the expected efficiency, the majority of states provide business court judges with full administrative staff support. ${ }^{138}$

\section{Costs and Filling Fees}

One barrier that may keep a state from pursuing the benefits of a business court program is a lack of funding. ${ }^{139}$ This begs the question, "How does a state cover the costs?"140 Some states have been able to implement a business court program without burdening the budget, solely by imposing extra filing fees. ${ }^{141}$ These extra fees can be as modest as the cost of transferring a case from the regular court system to the business court. ${ }^{142}$ The average filing fee from the business courts in the United States is around $\$ 300$, while the highest can be found in Arizona at $\$ 750 .{ }^{143}$ Finally, some states procure funds from their legislature or supreme court to adequately staff the business court program. ${ }^{144}$

130. Id

131. SulLivan \& Wessel, supra note 10 , at 7.

132. $I d$.

133. $I d$.

134. Id.

135. Renck \& Thomas, supra note 37 , at 2.

136. Id.

137. Sullivan \& Wessel, supra note 10 , at 6.

138. $I d$.

139. Id. at 5 .

140. Id.

141. Id.

142. Id.

143. Id.

144. Id. 


\section{Routes of Appeal}

Having appropriate routes of appeal is essential to curb any possible negative associations with the business court's public perception. ${ }^{145}$ Most cases follow the typical route of appeal that any civil case in its jurisdiction would follow. ${ }^{146}$ However, because the majority of cases involve complex issues and have widespread impact on future business litigation within the state, some states allow appeals from business court to travel directly to the highest court in the state. ${ }^{147}$

\section{E. Minimum Amount in Controversy}

As with all of the decisions mentioned above, choosing an amount in controversy requirement must be made to align with the particular goals of the state implementing the business court. ${ }^{148}$ For example, South Carolina chose not to place an amount in controversy requirement as a prerequisite to filing within its business court. ${ }^{149}$ South Carolina was concerned such a requirement would preclude important disputes from being pursued and would reduce the benefit that the business court provides overall. ${ }^{150}$ Other states, perhaps those with large, industrial cities, may find that an amount in controversy is required to free the commercial docket of congestion. ${ }^{151}$

\section{F. Voluntary Filing and Transfer}

States vary on whether to make filing within the business court mandatory for any case meeting the requirements. ${ }^{152}$ Many states believe that allowing voluntary filing will give litigating parties more options of dispute resolution and encourage them to file within the court. ${ }^{153}$ However, some states find the court's overall benefit increases if parties are required to file within the business court when their case type meets the requirements. ${ }^{154}$ In addition, these states typically allow filing directly into the business court, while others require the case to be transferred at the consent of both parties. ${ }^{155}$ In the pursuit of maximum accuracy and efficiency, some states have appointed an administrator to determine whether cases will be accepted, instead of accepting cases based on a list of specified criteria. ${ }^{156}$

145. Powell, supra note 14 , at 838.

146. Sullivan \& Wessel, supra note 10 , at 6 .

147. Id.

148. Id.

149. Id.

150. Id.

151. Id.

152. Id.

153. Id.

154. Id.

155. Id. at 7 .

156. Id. 


\section{Recommendations: Unique Attributes of Successful Business COURTS}

By analyzing the twenty-seven business courts across the country, one can observe strong trends and leading courtrooms that are beginning to emerge. The key to developing a successful business court is to determine what each state has done well and mimic the strategies that have proven useful, while still aligning with the state's specific goals. ${ }^{157}$ By implementing the following best practices from around the nation, a business court's likelihood of success and acceptance is greatly increased. ${ }^{158}$

\section{A. Begin by Developing a Pilot Program}

A pilot program begins with a committee of members dedicated to molding the business court to fit correctly with that specific state's objectives and corporate landscape. ${ }^{159}$ These programs essentially create the business court on a county-to-county scale to determine how well the court is received and what must change before implementing the business court on a state-wide level. ${ }^{160}$ The benefits of having a pilot program are the flexibility and adaptability that such a program offers early on in the business court's decision-making process. ${ }^{161}$

To uniquely mold a business court for its state, a pilot program must diligently track performance. ${ }^{162}$ This includes everything from what types of cases were successfully handled to surveying attorneys to determine points of improvement. ${ }^{163}$ Many surveys have found that lack of awareness of the business court as a resource to litigants was a serious problem. ${ }^{164}$ Therefore, a main concern for pilot programs is to educate the attorneys and businesses that will be working within its jurisdiction. ${ }^{165}$

Because one of the most difficult decisions in beginning a business court pilot program is determining the type of cases allowed into the business court, many pilot programs have the state's chief justice preside as "gatekeeper." "gatekeeper" means that for each case filed in the state's business court, the chief justice decides whether the court's jurisdiction would be appropriate for the parties and issues involved in the case. ${ }^{167}$ This allows the chief justice to monitor the program and make adjustments as trends start to develop from case to case.

157. See generally Nees, supra note 1 .

158. Id.

159. Sullivan \& Wessel, supra note 10 , at 13.

160. $I d$.

161. Id.

162. Id.

163. Id.

164. $I d$.

165. Id.

166. Roberts et al., supra note 2 , at 35 .

167. Id. 
An important element of any pilot program is this adaptability. ${ }^{168}$ For example, should a complex corporate issue present itself before the business court that would fail to meet the requirements allowed for the court's jurisdiction, the chief justice could permit the complex matter to enter the court anyway and advise the pilot program committee that the policy should be amended to include this new type of complex dispute in the future. ${ }^{169}$

\section{B. Policies to Ensure Efficiency}

With efficiency as one of the main benefits of a business court program, many states have implemented specific policies in an effort to maximize this effect. ${ }^{170}$ Policies such as "mediation programs, case management scheduling conferences, and case tracking programs" reduce not only the amount of time it takes to resolve a dispute, but also the amount of resources the court and litigants exhaust to do so. ${ }^{171}$ Around half of the business courts operate mediation programs as a resource for litigants to resolve disputes, but states differ on the necessity of such programs. ${ }^{172}$ Some of these courts have decided to make mediation mandatory, voluntary, or only by court order. ${ }^{173}$ Furthermore, some of the most successful business courts "utilize some form of a required case management conference and scheduling orders as a required case management tool." $" 174$ Due to the often large size of discovery requests involved in complex business disputes, required case management and scheduling orders allow parties to create an efficient schedule regarding motions, discovery, hearings, and trial dates. $^{175}$

For example, in 2003 the Delaware Court of Chancery began its Business and Technology Case Management Program (BTCMP). ${ }^{176}$ This made Delaware the first state with a business court that specifically includes technology disputes and proactively handles the large and complex discovery often associated with these types of disputes. ${ }^{177}$ Case tracking is another tactic utilized to pursue efficiency. ${ }^{178}$ This assigns different types of cases to predetermined resolution times and scheduling dates. ${ }^{179}$ For example, if a complex case has a resolution goal of eighteen months, there are predetermined windows for when discovery or

168. Id.

169. Id.

170. Nees, supra note 1 , at 520-21.

171. Id. at 520 .

172. Id.

173. Id.

174. Id.

175. Id. at 520-21.

176. Applebaum, supra note 6 , at 15 .

177. Id.

178. Nees, supra note 1, at 521.

179. Id. 
motions for summary judgment are to be addressed. ${ }^{180}$

New York's business court is one of the leading examples of how certain policies can improve efficiency within a business court. ${ }^{181}$ The state has experienced great success by implementing "earlier assignment of cases, more robust expert discovery rules, limits on privilege logs, the creation of standardized forms, and enhancements to the management of e-discovery issues. ${ }^{182}$ New York also follows a strict case management strategy. ${ }^{183} \mathrm{New}$ York requires staggered appearances, telephone discovery conference options, and an increase in the judge's participation in early discovery disputes. ${ }^{184}$ Each of these policies allow New York to remain a leader in efficiency. ${ }^{185}$

\section{Policies to Ensure Quality}

A prerequisite for the business court to be well-received must be a dedication to providing quality judicial services and quality written opinions. ${ }^{186}$ Judicial training and close collaboration with the state's bar association ensure cohesion within the state's current legal programs and help maintain the quality litigants of that state have come to expect. ${ }^{187}$ Perhaps the most important route a business court can pursue to ensure quality is for its judges to issue published legal opinions. ${ }^{188}$ This is a rarity as compared with other trial courts because trial opinions and dispositive motions are sparsely published. ${ }^{189}$

By creating a source of case law, judges have precedent on which to rely. ${ }^{190}$ This doctrine of law only grows and provides mores stability as more cases filter through the business court program. ${ }^{191}$ This is also a major component in ensuring the benefit of predictable case law to incentivize corporations to do business within the state. ${ }^{192}$ By issuing opinions, the business court has solidified this incentive and has increased the quality the court offers. ${ }^{193}$ Additionally, even when judges cycle out and the bench changes, this case law will ensure consistent, quality opinions within the business court. ${ }^{194}$

180. Id.

181. Robert L. Haig, Commercial Litigation in New York State Courts, 2 N.Y. Practice Series $\S 1: 7$ (3d ed. 2010).

182. Id.

183. Id.

184. Id.

185. Id.

186. Nees, supra note 1, at 521.

187. Id.

188. Roberts et al., supra note 2, at 32 .

189. Nees, supra note 1, at 521.

190. Roberts et al., supra note 2, at 32.

191. Id.

192. Id.

193. Id.

194. Nees, supra note 1, at 521. 


\section{Resources Available to Assist in the Creation of a Business Court}

An important tactic that a state may utilize to ensure the success of its business court is to consult the vast array of resources the legal profession has dedicated to this specific objective. ${ }^{195}$ The American Bar Association's Business Law Committee has published a document titled "Establishing Business Courts in Your State" as a resource for states considering pursing business courts. ${ }^{196}$ The Committee on Business and Corporate Litigation has a web page devoted to addressing business court resource distribution. ${ }^{197}$ The University of Maryland School of Law's Journal of Business and Technology Law maintains a similar webpage for states to utilize. ${ }^{198}$ Finally, the National Center for State Courts has an online presence devoted to business courts as well. ${ }^{199}$

\section{INDIANA's JOURNEY: IMPLEMENTING A BUSINESS COURT OF ITS OWN}

On June 2, 2015, the Indiana Supreme Court handed down its "Order Establishing the Indiana Commercial Court Working Group."200 This Order assigned nineteen prominent members of the Indiana legal community to participate in the Commercial Court Working Group, with the aspiration of implementing a commercial court of its own in Indiana. ${ }^{201}$ Members of the Working Group balance all interests associated with Indiana's commercial court and include: judges such as Judge Craig Bobay, Judge Heather Welch, and Justice Steven David; private practice attorneys such as Karen Moses and Michael Wukmer; and professors such as Professor Frank Sullivan and Professor Jay Tidmarsh. ${ }^{202}$

The goal of the Commercial Court Working Group was to "recommend guidelines for establishing and administering commercial courts" with a specific emphasis on: (1) case eligibility criteria; (2) commercial court education initiatives; (3) procedures for publishing opinions and appointing state paid masters; (4) best complex litigation practices; (5) community involvement; and (6) court staff funding sources. ${ }^{203}$ The Indiana Commercial Court W orking Group had only four short months to consider these elements and draft official recommendations for the Indiana Supreme Court. ${ }^{204}$ On October 1, 2015, the Working Group submitted its "Initial Report of the Indiana Commercial Court Working Group to the Indiana Supreme Court" stating it unanimously

195. RENCK \& THOMAS, supra note 4 , at 3.

196. Id. at 2 .

197. Id.

198. Id.

199. Id.

200. INITIAL REPORT, supra note 18 , at 1.

201. Id.

202. Id

203. Id. at $1-2$.

204. Id. at 2 . 
recommended establishing the Commercial Court pilot program in Indiana and provided a draft of rules intended to govern the procedures of the court. ${ }^{205}$

\section{A. Case Eligibility Criteria}

On October 1, 2015, the Indiana Commercial Court Working Group submitted Administrative Rule 20, the proposed rules governing the procedures of Indiana's commercial court. ${ }^{206}$ Administrative Rule 20 states that any civil case is eligible for the commercial docket as long as the central issue relates to any of the following criteria: (1) the formation, dissolution, governance, or liquidation of a business entity; (2) obligations between owners, officers, directors, partners, and a business entity; (3) trade secrets, non-competes, or employment agreements; (4) liability or indemnity of owners, officers, directors, partners, and the business entity; and (5) disputes between business entities or individuals relating to contracts, transactions, or their respective relationships. ${ }^{207}$

This fifth guideline leaves the Indiana commercial court subject to claims from both business entities and private individuals. ${ }^{208}$ By leaving the commercial court open to claims arising from individuals, Indiana significantly reduced the threat of a purely pro-business bias or pro-business public perception. ${ }^{209}$ The final guideline for case eligibility states "cases otherwise falling within the general intended purpose of the Commercial Docket" will be allowed to file within the commercial court. ${ }^{210}$ This provision demonstrates the pilot program's flexibility and ability to adapt. ${ }^{211}$ Although it may prove difficult to anticipate every possible situation in which the commercial court would prove to be a useful resource, this provision allows Indiana's commercial court to take claims not otherwise allowed and provides an opportunity to revise Administrative Rule 20 accordingly. ${ }^{212}$

Administrative Rule 20 also specifies claims to which the commercial court is not intended to apply. ${ }^{213}$ The Indiana Commercial Court will not be an option for claims focusing on issues of: (1) personal injury, survivor, or wrongful death; (2) product liability and consumer protection; (3) discrimination; (4) individual residential real estate disputes; (5) matters subject to domestic relations, juvenile, or probate divisions of a court; (6) criminal matters; and (7) consumer debts. ${ }^{214}$ These exclusions seem to suggest that the Indiana Commercial Court intends to

205. Id. at 4 .

206. Ind. Commercial Court Working Grp., Indiana Commercial Court Rule 20: Commercial Courts Draft 1 (2015) (unpublished draft) (on file with the Indiana Law Review) [hereinafter Rule $20]$.

207. Id. at 2-3.

208. Id. at 3 .

209. Roberts et al., supra note 2, at 33.

210. Rule 20, supra note 206, at 4.

211. Roberts et al., supra note 2, at 33.

212. Rule 20, supra note 206 , at 4 .

213. Id.

214. Id. 
focus on claims that revolve around the business transaction itself and not subsequent consumer or personal injury disputes. ${ }^{215}$ These rules offer a great foundation for establishing the specific claims eligible for Indiana's commercial court, all while maintaining the flexibility that will allow for growth and specialization. ${ }^{216}$

\section{B. Publication of Orders and Commercial Court Staff}

A large portion of the Indiana Commercial Court Working Group's proposal focused on the staffing and funding requirements that will be necessary to run the program and publish opinions. ${ }^{217}$ Administrative Rule 20 states that the commercial court will publish opinions electronically on its "dispositive motions, trials, and other significant matters." ${ }^{218}$ The Working Group has suggested that all commercial courts run on the Odyssey ${ }^{219}$ case management system. ${ }^{220} \mathrm{~W}$ ith all of the judges using the same system, electronic filing through Odyssey should be the most effective pathway for publication. ${ }^{221}$ The Commercial Court Working Group anticipates that all Indiana commercial court venues will utilize Odyssey and have e-filing as an option before the commercial court docket is initiated. ${ }^{22}$

One of the only areas that the Working Group did not unanimously agree upon was the procedure that outlines the appointment of commercial court masters. ${ }^{223}$ A commercial court master is an "attorney, a senior judge, or a nonattorney agreed upon by the Commercial Docket Judge . . who has special skills or training appropriate to undertake to perform the tasks that may be required."224 In contrast to Indiana Trial Rule 53(A), the Commercial Docket Judge will be able to appoint a master without obtaining the permission of the Indiana Supreme Court. ${ }^{225}$ The debate involving the appointment of masters hinged on deciding whether the Commercial Docket Judge should have the sole discretion to appoint or have to get the consent of the parties before assigning the master. ${ }^{226}$

With a vote of 13-3, the Working Group proposed that the Commercial Docket Judge be required to obtain the express consent of the parties before

215. $I d$.

216. Id. at 3-4.

217. Id. at 8 .

218. Id.

219. Odyssey is Indiana's statewide case management system that categorizes its courts' chronological case summaries.

220. INITIAL REPORT, supra note 18 , at 3.

221. Id.

222. Memorandum from Professor Frank Sullivan, Ind. Robert H. McKinney Sch. of Law, to the Ind. Commercial Court Working Grp., 1 (Jan. 21, 2016) (on file with author) [hereinafter Memorandum].

223. Rule 20, supra note 206 , at 8 .

224. Id.

225. INITIAL REPORT, supra note 18 , at 5.

226. Id. 
assigning a master to the case and that consent as to the master's compensation must be obtained, as well. ${ }^{227}$ One of the main reasons that the Working Group chose this route was that other states experienced concerns from individuals and business entities regarding how much control they retained over litigation. ${ }^{228} \mathrm{In}$ an effort to relieve this concern, the Working Group chose to require the parties' consent and thus provided litigants with more input in the management of their cases. ${ }^{22}$ Furthermore, filing within Indiana's commercial court docket will be voluntary, and in the interest of keeping this trend, consent of the parties must be obtained before filing in the business court as well as before appointing the master. ${ }^{230}$

A significant benefit of filing within the commercial court system is the ability to experience the precedent of the published motions and rulings. ${ }^{231}$ To make this a reality, Commercial Docket Judges must have the available resources to hire full-time staff, including law clerks. ${ }^{232}$ These law clerks are essential to providing promised efficiency, as they are expected to research a majority of the issues and draft opinions. ${ }^{233}$ Finding the resources to hire law school graduate law clerks, and to establish the entire program, is an obstacle Indiana must face. ${ }^{234}$ Although the Working Group is still collaborating with legislation to secure future funding, the initial funding for the Indiana Commercial Court pilot project will be found in the Indiana Supreme Court's budget. ${ }^{235}$

\section{Education}

With the Indiana Commercial Court Pilot Project in rapid development, education and awareness regarding the program will be fundamental to its early successful adoption. ${ }^{236}$ Indiana's Working Group will be partnering with the Indiana State Bar Association as well as the Indianapolis Bar Association. ${ }^{237}$ Jointly, their pooled resources and contacts will be able to adequately educate Indiana about its new judicial resource in the commercial court. ${ }^{238}$ This joint collaboration will be able to reach law firms, the Indiana community, and business entities alike. ${ }^{239}$ The majority of the members in the Commercial Court

227. Rule 20, supra note 206 , at 8.

228. Ind. Commercial Court Working Grp., Argument Supporting the View That Masters Should Be Appointed Only by Agreement of the Parties 1-2 (2015).

229. Id. at 1.

230. Id.

231. INITIAL REPORT, supra note 18 , at 7.

232. Id.

233. $I d$.

234. Id.

235. Id.

236. $I d$. at 3-4.

237. Id. at 3 .

238. Id.

239. Id. 
Working Group also participate in other legal associations across the state, such as the Indiana Chamber of Commerce and the Indiana Business Law Survey Commission, solidifying the Group's influence across Indiana's legal community. ${ }^{240}$

\section{Indiana's Current Position}

On October 29, 2015, Chief Justice Loretta H. Rush of the Indiana Supreme Court responded to the Indiana Commercial Court Working Group's initial report, rule draft, and future recommendations. ${ }^{241}$ After analyzing the Working Group's submission, the Indiana Supreme Court unanimously decided to proceed with establishing a Commercial Court Pilot Project in Indiana. ${ }^{242}$ On January 20, 2016, the Indiana Supreme Court issued an order officially establishing the Indiana Commercial Court Pilot Project in six counties. ${ }^{243}$ The Pilot Project will last for three years as a test phase to determine the best procedures for the court and whether to extend the court to more counties. ${ }^{244}$

The following Indiana judges will be the inaugural Commercial Docket Judges: Judge Craig Bobay, Allen Superior Court-Civil Division; Judge Stephen Bowers, Elkhart Superior Court 2; Judge Richard D'Amour, Vanderburgh Superior Court; Judge Maria Granger, Floyd Superior Court 3; Judge John Sedia, Lake Superior Court; and Judge Heather Welch, Marion Superior Court—Civil Division $1 .{ }^{245}$ These jurisdictions span the entire length of the state and the commercial courts established within them will provide a great judicial resource for Indiana's most concentrated business districts. The Indiana Supreme Court has also determined that it will provide funding for four law clerks. ${ }^{246}$ The Commercial Court W orking Group has suggested that Marion County be assigned one clerk, Floyd and Vanderburgh County share a clerk, and Lake, Elkhart, and Allen County share two clerks. ${ }^{247}$ The Indiana Commercial Court Pilot Project became fully functional in these counties on June $1,2016 .^{248}$

\section{CONCLUSION}

As the effect that corporations have on our economy increases, more states are following the trend of implementing business courts to handle the complex litigation that often follows large companies and their consumer interactions. ${ }^{249}$ With judges trained in business disputes presiding over cases from beginning to

240. Id. at 3-4.

241. Letter, supra note 21.

242. $I d$.

243. Order, supra note 21 , at 1.

244. Id.

245. Id.

246. Memorandum, supra note 222 , at 1.

247. Id.

248. Order, supra note 21 , at 1.

249. Roberts et al., supra note 2, at 32. 
end, business courts are providing states with efficiency, quality, common law predictability, and innovation. ${ }^{250}$ By streamlining these complex disputes, a state's entire court system benefits by eliminating docket backups and leaving more resources to devote to the numerous other cases filed within the state. ${ }^{251}$ The common law predictability that business courts provide offers a great incentive for businesses to incorporate or complete transactions within a state that has established business courts. ${ }^{252}$

Though business courts are sometimes met with skepticism, these perceived negatives are often overstated and can be solved by the implementation of simple policies and procedures. ${ }^{253}$ A state's fear that a business court fosters bias, negative public perception, and an isolation of elite judges is not supported by evidence and can be curbed by maintaining transparency within the court system. ${ }^{254}$ Specifying routes of appeal, rotating business court judges, and using case criteria requirements that allow an individual's claim against a business reduce these perceived negatives. ${ }^{255}$

To remain successful, there are a wide array of decisions a state must make to mold the business court to its state's specific goals and aspirations. ${ }^{256}$ Complex business courts, pure business courts, and complex civil courts are all options states have chosen in an effort to alleviate the pressures that large cases have on a courtroom's docket. ${ }^{257}$ Factors such as the case types allowed to be filed within the business court will determine the court's perception and direction. ${ }^{258}$ Filing fees, jury trials, location of the court, and the number of judges all must be made with the state's respective goals in mind. ${ }^{259}$

It is crucial for a state to implement a business court pilot program to "test the waters." 260 This allows a state to begin its business court on a small scale and make adjustments to fit the state's needs before opening the program statewide. ${ }^{261}$ To rival the most successful business courts in the country, states must implement procedures that ensure efficiency and quality. ${ }^{262}$ Mediation, case management programs, discovery rules, published opinions, and judicial training are all unique solutions various states have pursued to be competitive. ${ }^{263}$ There is also a vast amount of resources available for states considering a business court to consult

250. See generally Sullivan \& WeSSEL, supra note 10.

251. Applebaum, supra note 6, at 17.

252. See generally SulLIVAN \& WeSSEL, supra note 10.

253. See generally Powell, supra note 14.

254. See generally Nees, supra note 1.

255. Id. at 496-97.

256. See generally Powell, supra note 14.

257. Sullivan \& Wessel, supra note 10 , at 1 .

258. Jackson, supra note 128.

259. See generally Nees, supra note 1.

260. Sullivan \& Wessel, supra note 10 , at 13.

261. $I d$.

262. Nees, supra note 1 , at 520-22.

263. Id. 
on how to make the court the most successful. ${ }^{264}$

Indiana's recent initiative to pursue a Commercial Court Pilot Project shows the state is dedicated to providing the best possible judicial resolution process available for all of its litigants. ${ }^{265}$ The Commercial Court Working Group's draft of Administrative Rule 20 displays the framework for a commercial court that is geared toward taking the most complex business disputes away from the general docket and placing them into a commercial court system that will have the resources to effectively resolve them. ${ }^{266}$ On June 1, 2016, the Indiana Commercial Court Pilot Project became operational, and Indiana secured a great judicial advantage and resource for its legal community. ${ }^{267}$ In conclusion, business courts' benefits far outweigh any negative effects, and by following the policies implemented by the most successful business courts in the nation, Indiana, and any other state, can establish a business court to overcome the hardships of complex business litigation within its jurisdiction. ${ }^{268}$

264. See generally RENCK \& THOMAS, supra note 4, at 3 .

265. Letter, supra note 21.

266. Rule 20, supra note 206 , at 8 .

267. Order, supra note 21 , at 1.

268. See generally Nees, supra note 1 . 